\title{
ANALISIS PERBANDINGAN PENGARUH PENGUNGKAPAN DAN TRANSAKSI PIHAK BERELASI TERHADAP NILAI PERUSAHAAN PADA SEKTOR PROPERTI
}

\author{
Anindita Dresti ${ }^{1)}$; Devenni Putri Fau ${ }^{2}$ \\ 1) 1401190170.aninditadresti@gmail.com, Politeknik Keuangan Negara STAN \\ 2) devenni.pfau@gmail.com, Politeknik Keuangan Negara STAN \\ * untuk penulis korespondensi
}

\begin{abstract}
The tendency to prioritize profit is a big factor for companies to take advantage of various loopholes to maximize revenue and minimize costs and expenses. One which include transactions with related parties which are a means of manipulating sales and purchases to beautify financial reports to attract investors. Almost all companies have transactions with related parties, not always in a negative way, but it is necessary to be aware of any frauds committed due to differences in the treatment of related parties. Therefore, the analysis of related party transactions is carried out to see how the investors perceived the value of the company, especially in the property sector, which has a number of large and material transactions and is still of little concern. The study was conducted by comparing the value of companies that have related party transactions that in line with PSAK 7 and those that do not. The research showed that related party transactions still have a small effect on firm value.
\end{abstract}

Keywords: firm value, property sector, related-party transaction

\begin{abstract}
Abstrak
Kecenderungan untuk memprioritaskan keuntungan atau laba menjadi faktor penentu bagi perusahaan untuk memanfaatkan berbagai celah untuk memaksimalkan pendapatan serta meminimalisir biaya dan pengeluaran. Tidak terkecuali transaksi dengan pihak berelasi yang menjadi sarana manipulasi penjualan maupun pembelian untuk memperindah laporan keuangan demi menarik minat investor. Hampir seluruh perusahaan tentu memiliki transaksi dengan pihak berelasi, yang tidak selalu berkonotasi negatif, namun perlu diwaspadai adanya kecurangan-kecurangan yang dilakukan karena perbedaan perlakuan terhadap pihak berelasi. Untuk itu, analisis terhadap transaksi pihak berelasi ini dilakukan untuk melihat bagaimana nilai perusahaan di mata para investor di Indonesia, terutama pada sektor properti yang memiliki nominal transaksi yang besar dan masih menjadi sedikit perhatian. Penelitian dilakukan dengan membandingkan nilai perusahaan yang memiliki transaksi pihak berelasi yang memenuhi PSAK 7 dengan yang tidak. Penelitian memberikan hasil bahwa transaksi pihak berelasi memiliki pengaruh yang tidak besar terhadap nilai perusahaan.

Kata kunci: nilai perusahaan, sektor properti, transaksi pihak berelasi.
\end{abstract}

\section{PENDAHULUAN}

Maksimalisasi laba sebagai salah satu tujuan utama perusahaan merupakan selisih antara pendapatan dengan beban yang menjadi refleksi kegiatan operasional perusahaan dalam laporan keuangan (Christiawan \& Tarigan, 2007). Laba dengan nilai sebesar-besarnya dilakukan dengan berbagai cara; salah satunya adalah pemanfaatan transaksi dengan pihak berelasi.

Nilai perusahaan adalah persepsi publik terhadap perusahaan yang sering dikaitkan dengan harga pasar saham yang biasanya mencerminkan kondisi perusahaan (Putri et al., 2019). Nilai perusahaan menjadi acuan atas 'image' perusahaan di pasar dan menjadi pedoman investor untuk melakukan investasi pada perusahaan yang bersangkutan. Informasi yang akurat dan relevan menjadi tolak ukur yang penting dalam penilaian perusahaan. Informasi dalam bentuk laporan keuangan misalnya, memberikan keterangan bagaimana kinerja perusahaan, jumlah pendapatan, utang, aset, dan modal perusahaan, jumlah pihak-pihak berelasi, dan rasio-rasio keuangan yang menjadi pertimbangan investor dalam menanamkan modalnya. Semakin transparan dan terpercaya informasi yang diberikan dalam laporan keuangan, maka akan semakin tinggi peluang investor memilih perusahaan sebagai investasinya. Informasi ini menjadi sangat penting karena berpengaruh besar terhadap nilai 


\section{JURNALKU}

Volume 1 No. 2, Juni 2021

perusahaan. Informasi yang relevan akan meningkatkan nilai perusahaan. Nilai perusahaan yang rendah karena informasi yang diberikan tidak akurat akan turut mengurangi kepercayaan pasar yang dapat berdampak buruk bagi kinerja perusahaan.

Terdapat berbagai faktor penentu kualitas informasi pada laporan keuangan, antara lain adalah dengan terpenuhinya aturan standar akuntansi yang berlaku. Salah satunya merupakan pemenuhan PSAK 7 mengenai Pengungkapan Pihak-pihak Berelasi. PSAK 7 mengatur tentang pengungkapan pihak-pihak berelasi yang dapat mempengaruhi posisi keuangan maupun laba rugi dalam laporan keuangan. Pengungkapan ini dilakukan dengan tujuan memberikan transparansi mengenai hubungan serta transaksi perusahaan dengan pihak-pihak berelasi karena hal tersebut dapat mempengaruhi penilaian atas operasi entitas oleh pengguna laporan keuangan.

Menurut PSAK 7 yang merupakan adopsi dari IAS 24, laporan keuangan harus mengungkapkan dan mengidentifikasi pihak-pihak berelasi yang melakukan transaksi dengan perusahaan terlepas dari ada tidaknya harga yang dibebankan. Pihak-pihak berelasi adalah orang atau entitas yang terkait dengan entitas tertentu dalam menyiapkan laporan keuangannya, seperti anggota keluarga, anggota manajemen kunci, entitas yang berelasi dengan pemerintah, pihak yang mendapat kompensasi termasuk imbalan kerja dan lainnya.

Pihak-pihak berelasi atau related party harus diungkapkan sebagai syarat terpenuhinya standar dari laporan keuangan. Namun pada realisasinya, banyak perusahaan yang tidak melakukan pengungkapan pihak-pihak berelasi sesuai dengan ketentuan yang berlaku. Seperti pada kasus Enron di Amerika, dimana laporan keuangan mengakui pendapatan dari entitas pihak berelasi yang seharusnya tidak dapat diakui sebagai pendapatan perusahaan untuk meningkatkan laba sehingga berpengaruh dalam peningkatan nilai perusahaan. Kasus ini merupakan salah satu alasan mengapa pengungkapan pihak-pihak berelasi menjadi penting.

Kerancuan materialitas sebuah transaksi bagi perusahaan maupun pihak berelasi adalah salah satu faktor penyebab transaksi pihak-pihak berelasi tidak diungkapkan pada laporan keuangan. Financial Accounting Standard Board (FASB), atau Dewan Standar Akuntansi Keuangan Amerika Serikat menyatakan bahwa transaksi pihak-pihak berelasi tidak atau kurang memiliki arm's length principle sehingga rentan terhadap manipulasi oleh manajemen akibat konflik kepentingan (Kohlbeck dan Mayhew, 2010). Karena sifat transaksi dengan pihak-pihak berelasi yang tidak mengadopsi arm's length principle, maka transaksi dengan pihak-pihak berelasi dapat menimbulkan kecurigaan akan adanya konflik kepentingan yang akan menguntungkan pemegang saham pengendali dan merugikan pemegang saham minoritas.

Di Indonesia, selain aturan PSAK 7 yang diterbitkan Ikatan Akuntan Indonesia (IAI), Otoritas Jasa Keuangan (OJK) juga mengeluarkan Peraturan Nomor IX.E.1 tentang Transaksi Afiliasi dan Benturan Kepentingan Transaksi Tertentu dan Peraturan Nomor VIII.G.7 tentang Pedoman Penyajian Laporan Keuangan, khususnya pada bagian transaksi dengan pihak berelasi untuk menghindari dan meminimalisir transaksi pihak berelasi yang bisa merugikan kepentingan pemegang saham minoritas (Sari dan Artinah, 2018).

Walaupun transaksi pihak-pihak berelasi dapat memunculkan konflik kepentingan antara pemegang saham pengendali dan minoritas, transaksi pihak-pihak berelasi juga dapat memberikan dampak positif bagi perusahaan yaitu maksimalisasi laba dengan mengurangi biaya transaksi (Kang et al., 2014). Misalnya, beberapa perusahaan melakukan investasi strategis dalam usaha joint venture untuk memperoleh dan mengamankan akses kepersediaan atau pasar untuk mengelola risiko. Transaksi antara pihak-pihak berelasi dan perusahaan juga umumnya melibatkan lebih sedikit informasi antara kedua pihak, daripada yang biasa terjadi ketika transaksi terjadi antara perusahaan dan pihak ketiga lainnya.

Tidak adanya larangan transaksi dengan pihak-pihak berelasi juga menunjukkan bahwa transaksi dengan pihak-pihak berelasi tidak selalu menjadi masalah. Related party transaction 


\section{JURNALKU}

Volume 1 No. 2, Juni 2021

bahkan bisa menunjang efektivitas serta efisiensi perusahaan. Maka dari itu, dapat dikatakan bahwa transaksi pihak-pihak berelasi memiliki dual nature. Transaksi pihak-pihak berelasi dapat bersifat merugikan (abusive related party transaction) atau menguntungkan (efficient related party transaction) (Kohlbeck dan Mayhew, 2010).

Beberapa berpendapat bahwa transaksi pihak-pihak berelasi dapat digunakan untuk mencapai maksimalisasi nilai pemegang saham dengan mengurangi biaya transaksi dan dengan demikian mencapai skala ekonomi. Pasaribu et al. (2016) menguji pengaruh struktur kepemilikan yang dibagi menjadi kepemilikan institusional dan kepemilikan manajerial berdasarkan laporan keuangan perusahaan manufaktur sektor industri dasar dan kimia dan menemukan bahwa variabel struktur kepemilikan ini berpengaruh positif dan signifikan terhadap nilai perusahaan. Lubis et al. (2013) mengulas tentang hubungan antara transaksi pihak hubungan istimewa sesuai PSAK 7 menggunakan parameter aktiva piutang atau pemberian pinjaman dengan pihak berelasi pada perusahaan manufaktur dan berkesimpulan bahwa variabel ini berpengaruh positif dan signifikan terhadap nilai perusahaan. Sejalan dengan penelitian sebelumnya, Pratama (2018) meneliti pengaruh transaksi pihak berelasi terhadap nilai perusahaan pada perusahaan manufaktur dengan profitability, company size, dan leverage sebagai variabel kontrol dan menemukan bahwa transaksi pihak berelasi meningkatkan nilai perusahaan. Dengan demikian perusahaan Indonesia mendapat manfaat dari transaksi pihak berelasi dan bahwa pemegang saham tidak melihat transaksi pihak berelasi secara negatif.

Sementara yang lain berpendapat bahwa transaksi dengan pihak-pihak berelasi menghancurkan nilai perusahaan karena mereka timbul dari konflik kepentingan antara pemegang saham pengendali dengan pemegang saham minoritas dan dilakukan demi kepentingan pemegang saham pengendali untuk mengambil alih kekayaan dari pemegang saham minoritas. Kang et al. (2014) meneliti tentang hubungan kepemilikan terkonsentrasi yang mengarah pada divergensi voting rights dan cash flow rights atau yang biasa disebut sebagai control-ownership wedge dengan transaksi pihak-pihak berelasi dan efek transaksi pihak berelasi tersebut terhadap nilai perusahaan pada perusahaan-perusahaan grup besar di Korea. Hasil penelitiannya menunjukkan bahwa semakin agresif kepemilikan terkonsentrasi maka semakin tinggi keterjadian transaksi pihak berelasi namun nilai perusahaan menjadi semakin rendah. Di Indonesia, Septilestari et al. (2018) menguji pengaruh pengungkapan pihak berelasi serta pengungkapan transaksi dan saldo pihak berelasi terhadap nilai perusahaan sektor keuangan dan menemukan bahwa pengungkapan pihak berelasi serta pengungkapan transaksi dan saldo pihak berelasi tidak terbukti mampu menaikkan harga saham perusahaan. Putri et al. (2019) mengulas pengaruh transaksi pihak berelasi yang terindikasi tunneling yaitu dalam bentuk pinjaman kepada pihak berelasi terhadap nilai perusahaan dan berkesimpulan bahwa pinjaman yang diberikan kepada pihak berelasi berpengaruh negatif dan signifikan terhadap nilai perusahaan. Selain itu penelitian ini juga menunjukkan semakin besar ukuran perusahaan akan semakin besar nilai pinjaman yang diberikan kepada pihak berelasi karena perusahaan memiliki nilai aset yang lebih besar namun hal ini justru semakin menurunkan nilai perusahaan. Dengan demikian transaksi tersebut mencerminkan kepercayaan investor berkurang terhadap perusahaan apabila nilai pinjaman yang diberikan kepada pihak berelasi bernilai semakin besar.

Di sisi lain, Pozzoli dan Venuti (2014) dalam penelitian mengenai transaksi pihak berelasi dan nilai perusahaan pada perusahaan di Italia berkesimpulan bahwa transaksi dengan pihakpihak berelasi tidak berkorelasi dengan nilai perusahaan karena di Italia terdapat perlindungan yang kuat terhadap pemegang saham minoritas yang mengurangi risiko potensi penyalahgunaan dan potensi manfaat oleh pemegang saham mayoritas atau manajemen. Selain itu, Widari et al. (2016) menguji pengaruh transaksi pihak berelasi terhadap nilai perusahaan 


\section{JURNALKU}

Volume 1 No. 2, Juni 2021

pada perusahaan di Indonesia pada tahun 2014 dan menunjukkan bahwa transaksi pihak berelasi tidak mempengaruhi rata-rata abnormal pengembalian saham. Artinya pasar tidak bereaksi pada pengungkapan transaksi pihak berelasi serta investor tidak menggunakan informasi yang berhubungan dengan transaksi dengan pihak berelasi yang dipublikasikan dalam laporan tahunan perusahaan untuk mengambil keputusan.

Berbeda dengan penelitian yang telah disebutkan di atas, Kohlbeck dan Mayhew (2010) meneliti nilai perusahaan yang mengungkapkan transaksi dengan pihak berelasi dibandingkan dengan yang tidak. Menggunakan sampel sebanyak 1,194 perusahaan yang terdapat pada S\&P 1500 pada tahun 2001, sesaat sebelum Sarbanes-Oxley Act (SOX) melarang pinjaman kepada pihak-pihak berelasi, untuk mengevaluasi persepsi pasar terhadap perusahaan dengan transaksi pihak-pihak berelasi sebelum intervensi peraturan, penelitian ini menunjukkan hubungan negatif antara perusahaan yang mengungkapkan transaksi pihak berelasi dan nilai perusahaannya. Investor menghargai perusahaan yang mengungkapkan transaksi pihak berelasi sekitar 8\% (delapan persen) lebih rendah daripada perusahaan yang tidak mengungkapkan transaksi pihak berelasi. Analisis yang lebih mendalam menjelaskan bahwa investor menilai transaksi pihak berelasi berdasarkan jenis transaksi dan sifat pihak-pihak berelasi. Investor memandang secara negatif perusahaan yang mengungkapkan pinjaman kepada pihak-pihak berelasi dan mengadakan transaksi pihak- pihak berelasi yang sederhana seperti sewa dan jaminan dengan dewan direksi, pemegang saham, dan afiliasi. Sebaliknya, pengungkapan transaksi pihak-pihak berelasi yang kompleks dan transaksi pihak-pihak berelasi dengan investasi perusahaan seperti joint venture tidak mempengaruhi nilai perusahaan.

Bukti yang ada menunjukkan bahwa hubungan antara transaksi dengan pihak-pihak berelasi dan nilai perusahaan beragam dan jauh dari konklusif. Perbedaan hasil penelitian inilah yang menjadi pendorong untuk melakukan pengujian atas pengaruh pengungkapan dan transaksi dengan pihak-pihak berelasi terhadap nilai perusahaan. Seperti Kohlbeck dan Mayhew, penulis akan melakukan pengujian perbandingan nilai perusahaan di Indonesia antara perusahaan yang melakukan pengungkapan dan transaksi pihak-pihak berelasi dengan perusahaan yang tidak. Namun berbeda dengan penelitian sebelumnya, penelitian ini menggunakan nilai perusahaan sebagai variabel dependen, pengungkapan dan transaksi pihakpihak berelasi sesuai PSAK 7 sebagai variabel independen, dengan variabel kontrol berupa profitabilitas.

Maka dari itu, penelitian ini bertujuan untuk mengetahui pengaruh pengungkapan dan transaksi pihak-pihak berelasi terhadap nilai perusahaan serta mengetahui perbandingan nilai perusahaan antara perusahaan yang melakukan pengungkapan pihak berelasi sesuai PSAK 7 dengan yang tidak melakukan pengungkapan pihak berelasi sesuai PSAK 7.

\section{KAJIAN PUSTAKA}

Kohlbeck dan Mayhew (2010) mengungkapkan bahwa pihak-pihak berelasi memiliki pengaruh signifikan negatif terhadap nilai perusahaan. Kohlbeck meneliti perusahaan yang mengungkapkan transaksi dengan pihak berelasi dibandingkan dengan entitas yang tidak melakukan disclosure. Menggunakan sampel sebelum Sarbanes-Oxley Act (SOX) menerapkan pelarangan pinjaman kepada pihak-pihak berelasi, hasil penelitian ini menunjukkan hubungan negatif antara perusahaan yang mengungkapkan transaksi pihak berelasi dan nilai perusahaannya. Investor menghargai perusahaan yang mengungkapkan transaksi pihak berelasi sekitar 8\% (delapan persen) lebih rendah daripada perusahaan yang tidak mengungkapkan transaksi pihak berelasi. Analisis yang lebih mendalam menjelaskan bahwa investor menilai transaksi pihak berelasi berdasarkan jenis transaksi sederhana dan sifat pihakpihak berelasi. Investor memandang secara negatif perusahaan yang mengungkapkan pinjaman 


\section{JURNALKU}

Volume 1 No. 2, Juni 2021

kepada pihak-pihak berelasi dan mengadakan transaksi sederhana seperti sewa dan jaminan dengan dewan direksi, pemegang saham, dan afiliasi. Sedangkan pengungkapan transaksi pihak-pihak berelasi yang bersifat kompleks dan transaksi pihakpihak berelasi dengan investasi perusahaan seperti joint venture tidak mempengaruhi nilai perusahaan. Berdasarkan hasil penelitian, perusahaan yang melakukan pengungkapan pihak berelasi memiliki nilai yang lebih rendah dibanding dengan perusahaan yang tidak melakukan pengungkapan.

Septilestari, et. al (2018) menyatakan bahwa hasil penelitian menunjukkan tidak adanya pengaruh antara pihak berelasi dengan harga saham sebagai proksi nilai perusahaan. Penelitian dilakukan terhadap harga saham dengan variabel independen pengungkapan pihak berelasi dan pengungkapan transaksi dan saldo pihak berelasi. Namun, setelah dilakukan pengujian dan perhitungan dengan menggunakan program IBM SPSS Statistics 21 didapatkan bahwa hipotesis pengungkapan pihak berelasi berpengaruh terhadap kenaikan harga saham perusahaan sektor keuangan di Bursa Efek Indonesia (BEI) tahun 2014-2016 tidak terdukung. Hasil ini sesuai dengan hasil penelitian rujukan sebelumnya, yang menyatakan bahwa pengungkapan pihak berelasi tidak berpengaruh signifikan terhadap harga saham. Hal ini berarti pengguna laporan keuangan ataupun investor tidak terpengaruh akan pengungkapan pihak berelasi yang dilakukan perusahaan yang tercantum dalam laporan keuangan, sehingga tidak menggunakan informasi tersebut untuk dijadikan sebagai alat pengambil keputusan investasi ataupun keuangan. Informasi pengungkapan pihak berelasi pada perusahaan dianggap tidak cukup merefleksikan manajemen atau manipulasi laba yang kemungkinan besar dapat dilakukan melalui adanya hubungan dengan pihak berelasi.

Related party Transactions and Corporate Value oleh Ching-Chieh Tsai, L.-E. C.-L. (2015) menyatakan hasil empiris pengungkapan baik dari penjualan dan pembelian dengan pihak berelasi meningkatkan nilai perusahaan yang listing di Taiwan. Namun, ketika penjualan pihak berelasi lebih besar daripada pembeliannya, nilai perusahaan cenderung lebih rendah daripada perusahaan yang tidak mengungkapkan pihak berelasi karena menunjukkan motivasi tunneling dari transaksi pihak terkait. Mereka menyimpulkan bahwa sudah banyak studi tentang pengaruh pihak berelasi terhadap nilai perusahaan, namun tidak menjelaskan mengenai penyelesaian atas dampak terkait transaksi pihak berelasi yang mempengaruhi nilai perusahaan. Penelitian juga menghasilkan penjelasan tentang perspektif peran-peran pihak berelasi yang melakukan transaksi dengan perusahaan.

Pengaruh Transaksi Pihak-pihak Hubungan Istimewa Terhadap Kinerja Perusahaan oleh Khairunnissa (2018) meneliti masing-masing indikator transaksi pihak berelasi yaitu penjualan, pembelian, piutang, dan hutang terhadap nilai perusahaan yang diukur dengan metode Tobin's Q. Hasilnya adalah variabel piutang dan hutang tidak memiliki pengaruh signifikan terhadap kinerja perusahaan, dan variabel penjualan memiliki pengaruh negatif signifikan terhadap kinerja perusahaan, sedangkan variabel pembelian memiliki pengaruh positif signifikan terhadap kinerja perusahaan.

Kang et al. (2014) meneliti tentang hubungan kepemilikan terkonsentrasi yang mengarah pada divergensi voting rights dan cash flow rights atau yang biasa disebut sebagai controlownership wedge dengan transaksi pihak-pihak berelasi dan efek transaksi pihak berelasi tersebut terhadap nilai perusahaan pada perusahaanperusahaan grup besar di Korea. Hasil penelitiannya menunjukkan bahwa semakin agresif kepemilikan terkonsentrasi maka semakin tinggi keterjadian transaksi pihak berelasi namun nilai perusahaan menjadi semakin rendah.

Pengaruh Struktur Modal, Struktur Kepemilikan, dan Profitabilitas Terhadap Nilai Perusahaan Pada Perusahaan Sektor Industri Dasar dan Kimia yang Terdaftar di BEI Tahun 2011-2014 oleh Pasaribu et al. (2016) menguji pengaruh struktur kepemilikan yang dibagi menjadi kepemilikan institusional dan kepemilikan manajerial berdasarkan laporan keuangan perusahaan manufaktur sektor industri dasar dan kimia dengan teknik analisis linier berganda. 


\section{JURNALKU}

Volume 1 No. 2, Juni 2021

Hasil penelitian ini menemukan bahwa variabel struktur kepemilikan ini berpengaruh positif dan signifikan terhadap nilai perusahaan.

Putri et al. (2019) mengulas pengaruh transaksi pihak berelasi yang terindikasi tunneling yaitu dalam bentuk pinjaman kepada pihak berelasi terhadap nilai perusahaan menggunakan pengujian model regresi data panel dan berkesimpulan bahwa pinjaman yang diberikan kepada pihak berelasi berpengaruh negatif dan signifikan terhadap nilai perusahaan. Penelitian ini juga menunjukkan semakin besar ukuran perusahaan akan semakin besar nilai pinjaman yang diberikan kepada pihak berelasi karena perusahaan memiliki nilai aset yang lebih besar namun hal ini justru semakin menurunkan nilai perusahaan.

Pozzoli dan Venuti (2014) meneliti mengenai transaksi pihak berelasi dan nilai perusahaan pada perusahaan di Italia. Mereka berkesimpulan bahwa transaksi dengan pihakpihak berelasi tidak berkorelasi dengan nilai perusahaan karena di Italia terdapat perlindungan yang kuat terhadap pemegang saham minoritas yang mengurangi risiko potensi penyalahgunaan dan potensi manfaat oleh pemegang saham mayoritas atau manajemen.

Widari et al. (2016) menguji pengaruh transaksi pihak berelasi terhadap nilai perusahaan pada perusahaan di Indonesia pada tahun 2014 dan menunjukkan bahwa transaksi pihak berelasi tidak mempengaruhi rata-rata abnormal pengembalian saham. Artinya pasar tidak bereaksi pada pengungkapan transaksi pihak berelasi serta investor tidak menggunakan informasi yang berhubungan dengan transaksi dengan pihak berelasi yang dipublikasikan dalam laporan tahunan perusahaan untuk mengambil keputusan. Mereka menggunakan studi kasus dan pengujian analisis regresi berganda.

Lubis et al. (2013) mengulas tentang hubungan antara transaksi pihak hubungan istimewa sesuai PSAK 7 menggunakan parameter aktiva piutang atau pemberian pinjaman dengan pihak berelasi pada perusahaan manufaktur dan berkesimpulan bahwa variabel ini berpengaruh positif dan signifikan terhadap nilai perusahaan.

\section{METODE}

Penelitian berfokus pada nilai perusahaan sebagai variabel dependen yang dipengaruhi oleh variabel independen berupa pengungkapan dan transaksi pihak berelasi dengan variabel kontrol profitabilitas. Transaksi pihak berelasi berfokus pada 3 (tiga) transaksi yang paling sering dilakukan perusahaan yaitu Piutang, Utang, dan Imbalan Kerja. Objek penelitian adalah perusahaan sektor properti dengan menggunakan data sekunder berupa laporan keuangan dari BEI. Penelitian dilakukan pada laporan keuangan sektor properti mulai dari tahun pembaruan terakhir PSAK 7 yaitu 2014 hingga tahun 2018.

Penelitian ini akan dilaksanakan secara kuantitatif yang berfokus pada perbandingan nilai perusahaan yang menerapkan PSAK 7 mengenai pengungkapan dan transaksi pihak berelasi dengan yang tidak menerapkannya. Menurut Yusuf (2014), penelitian dengan pendekatan kuantitatif digunakan apabila data yang digunakan berupa data kuantitatif atau jenis data yang dapat dikuantitatifkan dan diolah dengan menggunakan teknik statistik. Data kuantitatif sendiri adalah data dalam bentuk angka yang umumnya diperoleh melalui pertanyaan terstruktur (Sekaran, 2017).

Informasi data yang digunakan merupakan data sekunder, dimana data yang diteliti merupakan data dari laporan keuangan masing-masing perusahaan yang telah diterbitkan dan diaudit. Jenis data yang digunakan merupakan data panel, yaitu data laporan keuangan perusahaan-perusahaan sektor properti dalam periode terbatas.

Populasi data yang diteliti adalah laporan keuangan perusahaan sektor properti pada periode tahun 2014 sampai dengan 2018. Periode ini dipilih untuk melihat perilaku perusahaan dalam menerapkan peraturan pengungkapan dan transaksi pihak berelasi pada laporan keuangannya, setelah terbitnya pembaruan PSAK 7 tentang Pihak Berelasi pada tahun 2014. 


\section{JURNALKU}

Volume 1 No. 2, Juni 2021

Sumber data yang digunakan merupakan data sekunder berupa laporan keuangan yang diterbitkan oleh BEI melalui situs resmi BEI dan situs masing-masing perusahaan.

Dari populasi data yang dibuat kemudian dilakukan pemilihan sampel data dengan menggunakan metode purposive sampling sebagai teknik pengambilan sampel. Dalam teknik ini, peneliti secara sengaja memilih unit-unit tertentu dari keseluruhan data untuk menyusun sampel yang dapat mewakili populasi (Kothari, 2004, p.59). Untuk menyusun sampel, digunakan kriteria-kriteria sebagai berikut: (1) Perusahaan yang terdaftar dalam sektor properti di BEI selama tahun 2014-2018; (2) Perusahaan yang menerbitkan laporan keuangan tahunan selama tahun 2014-2018; (3) Perusahaan yang sahamnya terdaftar dan aktif diperdagangkan di BEI selama tahun 2014-2018; (4) Perusahaan yang tidak delisting selama tahun 2014-2018.

\section{Hipotesis Penelitian}

Pengungkapan pihak berelasi berdasarkan PSAK 7 wajib dilakukan sebagai pemenuhan standar laporan keuangan yang berlaku. Pengungkapan dijelaskan dengan identifikasi pihak berelasi dan hubungan atas pihak berelasi tersebut. Walaupun hubungan pihak berelasi merupakan suatu karakteristik normal dalam transaksi perdagangan dan bisnis, pihak berelasi selaku pengendali atau pemilik pengaruh signifikan perusahaan dapat mempengaruhi laporan arus kas dan laporan keuangan yang bisa memunculkan kecurigaan dan pandangan negatif dari pasar. Hal ini juga dapat menimbulkan kemungkinan adanya konflik kepentingan oleh pemegang saham pengendali yang akan merugikan pemegang saham minoritas. Berdasarkan hal tersebut, maka diusulkan hipotesis sebagai berikut:

H1: Pengungkapan pihak berelasi berpengaruh negatif terhadap nilai perusahaan.

Selain pengungkapan pihak berelasi, transaksi, baik penjualan, pembelian, utang, dan piutang juga dapat memiliki dugaan sebagai suatu pengalihan sumber daya, jasa, atau kewajiban antar pihak yang juga dapat menimbulkan konflik kepentingan. Hal ini disebabkan kemungkinan pengalihan sumber daya untuk keuntungan salah satu pihak berelasi yang merupakan pihak pengendali perusahaan. Hal tersebut menjadi rujukan untuk menentukan hipotesis kedua, yaitu:

H2: Transaksi pihak berelasi berpengaruh negatif terhadap nilai perusahaan.

Selain meneliti pengaruh pengungkapan dan transaksi pihak berelasi terhadap perusahaan, seperti penelitian oleh Kohlbeck dan Mayhew (2010), penulis juga membandingkan nilai perusahaan yang melakukan pengungkapan pihak berelasi dengan perusahaan yang tidak. Hal ini menjadi fokus penelitian untuk melihat seberapa besar nilai perusahaan dipengaruhi oleh variabel-variabel independen sehingga diputuskan hipotesis ketiga sebagai berikut.

H3: Nilai perusahaan yang mengungkapkan dan melakukan transaksi dengan pihak berelasi lebih rendah dibandingkan perusahaan yang tidak mengungkapkan dan melakukan transaksi dengan pihak berelasi.

\section{HASIL DAN PEMBAHASAN Statistik Deskriptif}

Analisis statistik deskriptif digunakan untuk mendapatkan data sesuai topik penelitian. Analisis ini memberikan pemahaman terhadap deskripsi objek penelitian (Sekaran, 2016). Sedangkan menurut Kothari (2004), statistik deskriptif memfokuskan pada perkembangan informasi pada data mentah yang ada. Analisis statistik deskriptif menjadi penting sebagai deskripsi atas data dan informasi yang diteliti. 
Tabel 1. Statistik Deskriptif Seluruh Sampel

\begin{tabular}{|c|c|c|c|c|c|c|}
\hline & \multicolumn{4}{|c|}{ FIRM_VALUE PENGUNGKA } & \multicolumn{2}{|c|}{ IMBALAN_KE PROFITABILITA } \\
\hline & _ & PAN & PIUTANG & UTANG & RJA & $\mathrm{S}_{\text {_ }} \mathrm{ROE}_{-}$ \\
\hline$\overline{\text { Mean }}$ & 6.969155 & $\overline{56.59474}$ & 0.169315 & 0.025166 & 0.256334 & 102.4388 \\
\hline Median & 1.017402 & 33.50000 & 0.030977 & 0.001304 & 0.220133 & 7.580000 \\
\hline Maximum & 1015.800 & 533.0000 & 0.999886 & 0.323511 & 0.945969 & 17921.27 \\
\hline Minimum & 0.090000 & 8.000000 & 0.000000 & 0.000000 & 0.000000 & -29.66000 \\
\hline Std. Dev. & 73.59966 & 84.26532 & 0.271810 & 0.058166 & 0.180806 & 1299.594 \\
\hline Skewness & 13.66144 & 3.975533 & 1.865300 & 3.395709 & 1.189124 & 13.67369 \\
\hline Kurtosis & 187.7588 & 19.28474 & 5.402362 & 14.47985 & 4.726025 & 187.9817 \\
\hline Jarque-Bera & 276152.0 & 2599.931 & 155.8691 & 1408.457 & 68.36223 & 276815.2 \\
\hline Probability & 0.000000 & 0.000000 & 0.000000 & 0.000000 & 0.000000 & 0.000000 \\
\hline Sum & 1324.139 & 10753.00 & 32.16980 & 4.781536 & 48.70346 & 19463.38 \\
\hline Sum Sq. Dev. & 1023796. & 1342022. & 13.96347 & 0.639449 & 6.178584 & $3.19 \mathrm{E}+08$ \\
\hline Observations & 190 & 190 & 190 & 190 & 190 & 190 \\
\hline
\end{tabular}

Sumber: Hasil Pengolahan Eviews9

Berdasarkan tabel pada proksi FIRM_VALUE_PBV_, terlihat rata-rata nilai perusahaan sektor properti sebesar 6,96 dengan nilai maksimum 1015,80 dan nilai minimum 0,090. Maka dapat disimpulkan bahwa PBV perusahaan sektor properti memiliki range yang luas. Pada proksi variabel PENGUNGKAPAN, juga ditemukan range yang luas dengan minimum 8 pengungkapan hingga maksimum 533 pengungkapan. Namun rata-rata PENGUNGKAPAN pihak berelasi hanya sebesar 56 pengungkapan. Sehingga dapat disimpulkan bahwa sebagian besar perusahaan di sektor properti cenderung sedikit dalam mengungkapkan pihak berelasi.

Variabel transaksi pihak berelasi dibagi menjadi 3 (tiga) yaitu PIUTANG, UTANG, dan IMBALAN_KERJA. Dari ketiganya, IMBALAN_KERJA menjadi transaksi pihak berelasi yang paling besar nominal transaksinya yaitu 0.25 . Dibandingkan PIUTANG yang memiliki rata-rata 0.16 dan UTANG memiliki rata-rata terkecil sebesar 0.02. Pada transaksi PIUTANG dapat dilihat bahwa dalam satu tahun di satu perusahaan, ada transaksi piutang pihak yang mencapai 0.99 dari keseluruhan transaksi piutang. Begitu pula dengan transaksi IMBALAN_KERJA yang pada satu tahun di satu perusahaan mencapai 0.94 dari total beban gaji yang dibayarkan tahun tersebut. Namun juga terdapat peristiwa dimana tidak ada transaksi PIUTANG, UTANG, dan IMBALAN_KERJA dengan pihak berelasi dalam satu tahun di satu perusahaan sektor properti.

Berdasarkan penjelasan di atas, dapat disimpulkan bahwa nilai setiap variabel dependen dan variabel independen di sektor properti dalam rentang waktu 2014-2018 tidak homogen. Dalam pemilihan Model Regresi Data Panel dengan menggunakan Uji Chow, Uji Hausman, dan Uji Langrange Multiplier, didapat bahwa model yang paling tepat digunakan adalah Random Effect.

Tabel 2. Hasil Uji Model Regresi Data Panel Seluruh Sampel

\begin{tabular}{|c|c|c|c|}
\hline Variable & Coefficient & t-Statistic & Prob. \\
\hline PENGUNGKAPAN & $8.02 \mathrm{E}-05$ & 0.038940 & 0.9690 \\
\hline PIUTANG & -1.165511 & -2.680909 & 0.0080 \\
\hline UTANG & -1.234124 & -0.738833 & 0.4609 \\
\hline IMBALAN_KERJA & 0.603680 & 0.767590 & 0.4437 \\
\hline PROFITABILITAS_ROE__ & 0.056651 & 1085.136 & 0.0000 \\
\hline \multicolumn{3}{|l|}{} & 0.999848 \\
\hline R-squared & 0.999844 \\
\hline Adjusted R-Squared & 241839.9 \\
\hline F-statistic & 0.000000 \\
\hline Prob(F-statistic)
\end{tabular}

Sumber: Hasil Pengolahan Eviews9 


\section{JURNALKU}

Volume 1 No. 2, Juni 2021

Berdasarkan Adjusted R-squared sebesar 0.99 yang mendekati satu, dapat disimpulkan bahwa estimasi model regresi yang digunakan sudah tepat dan baik. Berarti nilai perusahaan dapat dijelaskan oleh variabel independen sebesar 99\%. Prob(F-statistic) kurang dari batas kritis 0.05 , maka model regresi dapat menjelaskan pengaruh antara variabel independen dengan variabel dependen atau terdapat paling sedikit 1 (satu) variabel independen yang siginifikan di dalam model. Berdasarkan hasil uji $\mathrm{T}$, hanya variabel PIUTANG yang berpengaruh negatif signifikan terhadap FIRM_VALUE_PBV dengan hasil kurang dari batas kritis 0.05 .

\section{Hasil Pengujian Sampel Yang Memenuhi PSAK 7}

Untuk metode pengujian pada sampel yang memenuhi PSAK 7, digunakan juga Random Effect Model dengan model pada tabel.

Tabel 3. Hasil Uji Model Regresi Data Panel Sampel Yang Memenuhi PSAK 7

\begin{tabular}{|c|c|c|c|}
\hline Variable & Coefficient & t-Statistic & Prob. \\
\hline PENGUNGKAPAN & 0.000489 & 0.442634 & 0.6611 \\
\hline UTANG & -3.056104 & -0.611991 & 0.5450 \\
\hline PIUTANG & -0.111274 & -0.159375 & 0.8744 \\
\hline IMBALAN_KERJA & 7.047607 & 2.686500 & 0.0115 \\
\hline PROFITABILITAS_ROE_ & 0.017478 & 1.959371 & 0.0591 \\
\hline \multicolumn{3}{|l|}{} & 0.300989 \\
\hline R-squared _ & 0.188246 \\
\hline Adjusted R-Squared & 2.669680 \\
\hline F-statistic & 0.040505 \\
\hline Prob(F-statistic)
\end{tabular}

Sumber: Hasil Pengolahan Eviews9

Berdasarkan Adjusted R-squared sebesar 0.18, dapat disimpulkan bahwa estimasi model regresi yang digunakan sudah cukup baik. Berarti nilai perusahaan dapat dijelaskan oleh variabel independen sebesar 18\%, sedangkan $82 \%$ dijelaskan oleh faktor lainnya. Prob (Fstatistic) kurang dari batas kritis 0.05 , maka model regresi dapat menjelaskan pengaruh antara variabel independen dengan variabel dependen atau terdapat paling sedikit 1 (satu) variabel independen yang siginifikan di dalam model. Berdasarkan hasil uji $\mathrm{T}$, hanya variabel IMBALAN KERJA yang berpengaruh positif signifikan terhadap FIRM_VALUE_PBV dengan hasil kurang dari batas kritis 0.05 .

\section{Hasil Pengujian Sampel Yang Tidak Memenuhi PSAK 7}

Hasil pengujian sampel yang tidak memenuhi PSAK 7 juga menggunakan Random Effect Model dengan hasil analisis pada tabel.

Tabel 4. Hasil Uji Model Regresi Data Panel Sampel yang Tidak Memenuhi PSAK 7

\begin{tabular}{|c|c|c|c|}
\hline Variable & Coefficient & t-Statistic & Prob. \\
\hline PENGUNGKAPAN & 0.013180 & 0.652790 & 0.5149 \\
\hline PIUTANG & -1.294314 & -2.598149 & 0.0103 \\
\hline UTANG & -1.002868 & -0.550630 & 0.5827 \\
\hline IMBALAN_KERJA & 0.478558 & 0.550560 & 0.5828 \\
\hline PROFITABILITAS_ROE_ & 0.056651 & 1022.706 & 0.0000 \\
\hline R-squared & 0.999863 \\
\hline Adjusted R-Squared & 0.999858 \\
\hline F-statistic & 214429.0 \\
\hline Prob(F-statistic) & 0.000000 \\
\hline
\end{tabular}

Sumber: Hasil Pengolahan Eviews9

Berdasarkan Adjusted R-squared sebesar 0.99, dapat disimpulkan bahwa estimasi model regresi yang digunakan sudah tepat dan baik. Berarti nilai perusahaan dapat dijelaskan oleh variabel independen sebesar 99\%. Prob(F-statistic) kurang dari batas kritis 0.05, maka model regresi dapat menjelaskan pengaruh antara variabel independen secara simultan dengan 


\section{JURNALKU}

Volume 1 No. 2, Juni 2021

variabel dependen atau terdapat paling sedikit 1 (satu) variabel independen yang siginifikan di dalam model. Berdasarkan hasil uji T, hanya variabel PIUTANG yang berpengaruh negatif signifikan terhadap FIRM_VALUE_PBV dengan hasil kurang dari batas kritis 0.05 .

\section{Pembahasan}

Berdasarkan hasil pengujian diatas, didapatkan bahwa hipotesis pengungkapan pihak berelasi berpengaruh negatif terhadap nilai perusahaan $(\mathrm{H} 1)$ tidak terdukung. Jika para stakeholder tidak yakin atas pengungkapan pihak berelasi yang dimunculkan oleh manajemen dalam laporan keuangan, maka mereka akan memberikan reaksi negatif, begitu juga sebaliknya. Namun hasil pengujian menunjukkan bahwa pengungkapan pihak berelasi tidak mempengaruhi nilai perusahaan.

Hasil pengujian ini selaras dengan hasil pengujian oleh Septilestari, et al. (2018) yang menyatakan bahwa pengungkapan pihak berelasi tidak berpengaruh terhadap kenaikan harga saham perusahaan. Walaupun jumlah pengungkapan pihak berelasi yang dilakukan perusahaan sektor properti beragam, dari paling sedikit 8 (delapan) pengungkapan hingga paling banyak 533 (lima ratus tiga puluh tiga) pengungkapan, namun informasi tersebut tidak diperhatikan dan tidak dipakai sebagai dasar pengambilan keputusan oleh stakeholder. Salah satu faktor yang mempengaruhi ialah ketidakpedulian stakeholder untuk memahami informasi pengungkapan pihak berelasi dalam laporan keuangan. Para pemangku kepentingan menganggap informasi pengungkapan pihak berelasi oleh perusahaan sudah menggambarkan keadaan perusahaan yang sebenarnya sehingga tidak ada asimetri informasi dalam laporan keuangan perusahaan, namun tidak menganggap informasi tersebut mempengaruhi keadaan perusahaan di masa kini atau mendatang.

Dari hasil penelitian ini juga dapat disimpulkan bahwa stakeholder lebih mempertimbangkan informasi yang bersifat finansial seperti laba rugi, neraca, atau informasi akuntansi terkait keberlangsungan usaha perusahaan daripada informasi non-finansial seperti pengungkapan nama, hubungan, serta sifat dalam pengungkapan pihak berelasi untuk mengambil keputusan investasi. Padahal perusahaan sektor properti bekerja sama dengan banyak pihak dalam setiap proyek yang dijalankan. Dengan mengetahui dan memahami rekanan yang diungkap oleh manajemen dalam laporan keuangan, stakeholder dapat menilai risiko bisnis perusahaan dengan lebih baik.

Berdasarkan hasil pengujian, dapat disimpulkan bahwa hipotesis transaksi pihak berelasi berpengaruh negatif terhadap nilai perusahaan $(\mathrm{H} 2)$ tidak terdukung. Transaksi pihak berelasi mendapat reaksi yang beragam dari para pemangku kepentingan.

Pertama, transaksi piutang berpengaruh negatif terhadap nilai perusahaan. Hal ini disebabkan oleh stakeholder yang melihat transaksi piutang secara signifikan dapat mempengaruhi arus kas perusahaan dan meningkatkan ketergantungan antar perusahaan dalam satu grup. Reaksi negatif tersebut memberikan sinyal bahwa terdapat konflik antara agen dengan prinsipal yang disebabkan adanya asimetri informasi antara agen yang membuat keputusan atas transaksi piutang dengan prinsipal yang merasa investasinya dipakai untuk kegiatan yang tidak produktif yaitu pemberian piutang kepada pihak berelasi yang bercirikan berbunga rendah atau tanpa bunga dengan masa pinjaman yang panjang.

Hasil penelitian ini sejalan dengan penelitian oleh Putri et al. (2019) yang menyimpulkan bahwa pinjaman yang diberikan kepada pihak berelasi berpengaruh negatif dan signifikan terhadap nilai perusahaan. Salah satu faktor penyebabnya ialah tidak terdapat peraturan yang membatasi jumlah penghapusan piutang sehingga dapat membuka celah bagi pemegang saham pengendali untuk melakukan tunneling sehingga menjadi konflik antara prinsipal dengan prinsipal.

Dapat disimpulkan bahwa transaksi piutang dipandang sebagai transaksi yang merugikan stakeholder dan mempengaruhi kinerja perusahaan di masa kini serta kelangsungan 


\section{JURNALKU}

Volume 1 No. 2, Juni 2021

perusahaan di masa mendatang. Sehingga stakeholder memperhatikan informasi terkait transaksi piutang dan menggunakan informasi tersebut sebagai dasar pengambilan keputusan.

Kedua, transaksi utang tidak berpengaruh terhadap nilai perusahaan. Berdasarkan perbandingan analisis statistik deskriptif antara transaksi piutang, utang, dan imbalan kerja, dapat dilihat bahwa transaksi utang memiliki porsi terkecil dari transaksi lainnya. Berarti transaksi utang tidak banyak terjadi diantara para pihak berelasi. Karena jumlah transaksi serta nominal transaksi yang tidak signifikan, maka stakeholder menganggap transaksi tidak berpengaruh atas kelangsungan usaha perusahaan. Sehingga tidak mempertimbangkan informasi transaksi utang tersebut sebagai bahan pengambilan keputusan.

Ketiga, transaksi imbalan kerja tidak berpengaruh terhadap nilai perusahaan walaupun transaksi imbalan kerja memiliki porsi terbesar dari transaksi lainnya. Para pengguna laporan keuangan tidak melihat transaksi imbalan kerja sebagai transaksi yang dapat meningkatkan ataupun menurunkan nilai perusahaan.

Stakeholder memandang imbalan kerja kepada dewan direksi, dewan komisaris, dan manajemen kunci sebagai biaya untuk menyelaraskan kepentingan antara prinsipal dengan agen. Transaksi imbalan kerja yang terjadi di perusahaan sektor properti dianggap sebagai transaksi dengan nominal yang wajar. Stakeholder tidak melihat imbalan kerja sebagai transaksi yang berpengaruh atas keberlangsungan perusahaan sehingga tidak menggunakan informasi ini sebagai bahan pengambilan keputusan.

Maka dari itu dapat disimpulkan bahwa stakeholder secara umum tidak menggunakan informasi finansial dalam bentuk piutang, utang, dan imbalan kerja dalam pengambilan keputusan. Tetapi tidak menutup kemungkinan bahwa investor memperhitungkan informasi finansial lain yang lebih mudah untuk dibandingkan seperti net income dan earning per share. Hasil penelitian ini juga dapat dimaknai bahwa stakeholder secara garis besar tidak peduli atas transaksi pihak berelasi kecuali transaksi yang dapat merugikan investasi mereka seperti piutang.

Berdasarkan hasil pengujian, hipotesis nilai perusahaan yang mengungkapkan dan melakukan transaksi dengan pihak berelasi lebih rendah dibandingkan perusahaan yang tidak mengungkapkan dan melakukan transaksi dengan pihak berelasi (H3) terdukung. Rata-rata nilai perusahaan yang mengungkapkan dan melakukan transaksi dengan pihak berelasi 7 (tujuh) kali lebih rendah dari perusahaan yang tidak mengungkapkan dan melakukan transaksi dengan pihak berelasi.

Transaksi imbalan kerja berpengaruh positif terhadap nilai perusahaan yang mengungkapkan dan melakukan transaksi dengan pihak berelasi. Hasil pengujian ini berbeda dari hasil pengujian keseluruhan sampel perusahaan sektor properti. Kondisi ini disebabkan oleh stakeholder yang menilai imbalan kerja yang diberikan kepada dewan direksi, dewan komisaris, dan manajemen kunci dapat mengurangi agency cost dan meningkatkan kinerja perusahaan. Sehingga stakeholder menghargai imbalan kerja yang dikeluarkan bagi penyelarasan kepentingan. Namun respon positif atas transaksi imbalan kerja tidak berpengaruh signifikan terhadap nilai perusahaan.

Di sisi lain, nilai perusahaan yang tidak mengungkapkan dan melakukan transaksi dengan pihak berelasi dipengaruhi secara negatif oleh transaksi piutang. Hal ini selaras dengan hasil pengujian seluruh sampel perusahaan sektor properti. Sehingga dapat dikatakan bahwa mayoritas perusahaan sektor properti tidak mengungkapkan dan melakukan transaksi pihak berelasi sesuai dengan PSAK 7. Seperti dijelaskan diatas, kondisi ini disebabkan oleh sikap stakeholder yang tidak menyetujui transaksi yang dapat merugikan mereka.

Selain itu, pada kedua sampel perusahaan sektor properti ini ditemukan bahwa pengungkapan tidak mempengaruhi nilai perusahaan. Hal ini memperkuat dugaan bahwa stakeholder tidak memperhatikan informasi non-finansial seperti pengungkapan pihak berelasi. 


\section{JURNALKU}

Volume 1 No. 2, Juni 2021

Dengan demikian, dapat disimpulkan bahwa stakeholder tidak peduli untuk memahami informasi non-finansial pada laporan keuangan. Stakeholder hanya mempertimbangkan informasi finansial yang dapat merugikan mereka. Pada akhirnya, pengungkapan dan transaksi pihak berelasi tidak mempengaruhi pengambilan keputusan oleh para pemangku kepentingan yang menggunakan informasi di laporan keuangan.

Hasil penelitian ini selaras dengan penelitian oleh Widari et al. (2016) yang menyatakan bahwa transaksi pihak berelasi tidak mempengaruhi rata-rata abnormal pengembalian saham. Menurut Widari et al. hal ini berarti pasar tidak bereaksi pada pengungkapan transaksi pihak berelasi serta investor tidak menggunakan informasi yang berhubungan dengan transaksi dengan pihak berelasi yang dipublikasikan dalam laporan tahunan perusahaan untuk mengambil keputusan. Hasil ini juga dapat diinterpretasikan bahwa para stakeholder menganggap pengungkapan dan transaksi pihak berelasi adalah suatu hal yang wajar dalam operasional perusahaan. Stakeholder tidak melihat pengungkapan dan transaksi pihak berelasi sebagai mekanisme untuk mengeksploitasi sumber daya perusahaan untuk kepentingan dewan direksi atau pemegang saham pengendali (conflict of interest transaction hypothesis). Namun sebagai transaksi normal atau pertukaran bisnis yang sehat antar perusahaan untuk memenuhi kebutuhan ekonomi sehingga transactions costs dapat diturunkan dan efisiensi ditingkatkan.

Hasil penelitian ini tidak sama dengan hasil penelitian Kohlbeck dan Mayhew (2010) yang menjadi rujukan replikasi penelitian ini. Terdapat perbedaan karakteristik antara pengguna laporan keuangan Indonesia dan Amerika Serikat. Stakeholder Amerika Serikat diduga lebih peduli untuk memahami nama, hubungan, serta sifat dalam pengungkapan pihak berelasi, serta sifat dan nominal transaksi pihak berelasi. Sehingga pengungkapan dan transaksi pihak berelasi menjadi pertimbangan para pemangku kepentingan saat mengambil keputusan investasi.

\section{PENUTUP \\ Simpulan}

Hasil dari model analisis regresi menunjukkan bahwa pengungkapan pihak berelasi tidak berpengaruh terhadap nilai perusahaan. Hal ini diduga karena mayoritas investor di Indonesia tidak memprioritaskan aspek pengungkapan pihak berelasi dalam melakukan keputusan investasi. Tidak seperti investor di negara seperti Amerika Serikat yang lebih memperhatikan aspek pihak berelasi akibat kasus kebangkrutan besar beberapa perusahaan yang pernah terjadi di negaranya, karena adanya manipulasi laporan keuangan yang ditutupi dengan transaksi pihak berelasi.

Transaksi pihak berelasi juga tidak berpengaruh terhadap nilai perusahaan. Dari tiga proksi yang ditentukan yaitu piutang, utang, dan imbalan kerja, hanya transaksi piutang yang memiliki pengaruh signifikan negatif terhadap nilai perusahaan. Sedangkan utang dan imbalan kerja tidak berpengaruh terhadap nilai perusahaan. Karena hanya satu diantara tiga proksi yang memiliki pengaruh, maka disimpulkan bahwa transaksi pihak berelasi secara keseluruhan tidak memiliki pengaruh terhadap nilai perusahaan. Hal ini diduga karena stakeholder tidak memperhatikan informasi transaksi pihak berelasi dan lebih memperhitungkan informasi finansial lain yang lebih mudah untuk dibandingkan.

Pada perbandingan pemenuhan perusahaan yang mengungkapkan transaksi pihak berelasi dan yang tidak mengungkapkan dengan ketentuan memenuhi PSAK 7, ditemukan bahwa perusahaan yang telah memenuhi memiliki rata-rata nilai perusahaan lebih rendah dibandingkan dengan perusahaan yang tidak memenuhi pengungkapan pihak berelasi. Nilai perusahaan yang tidak melakukan pengungkapan pihak berelasi sesuai PSAK 7 cenderung memiliki rata-rata nilai perusahaan yang tinggi. Keadaan ini membuktikan bahwa nilai 


\section{JURNALKU}

Volume 1 No. 2, Juni 2021

perusahaan yang melakukan pengungkapan pihak berelasi sesuai dengan PSAK 7 lebih rendah dibanding perusahaan yang tidak melakukan pengungkapan yang sama.

\section{Keterbatasan Penulisan}

Penulis menyadari masih terdapat ketidaksempurnaan terhadap penelitian ini yang disebabkan adanya keterbatasan-keterbatasan. Pertama, objek penelitian hanya meliputi perusahaan pada sector properti dan real estate yang terdaftar pada BEI. Kedua, variabel independen transaksi pihak berelasi hanya diproksikan pada piutang, utang, dan imbalan kerja manajemen, sehingga penelitian selanjutnya dapat menggunakan proksi yang lebih banyak dan bervariatif untuk mendapat hasil yang berbeda dan lebih mewakilkan. Ketiga, penelitian dilakukan hanya pada periode lima tahun yaitu 2014-2019. Hasil yang berbeda dapat diharapkan jika penelitian dilakukan pada periode yang berbeda.

\section{Implikasi}

Hasil penelitian ini diharapkan dapat membantu investor dalam menentukan investasi karena permintaan dan penawaran pasar yang dilakukan oleh investor mempengaruhi naik turunnya harga saham sebagai nilai perusahaan. Oleh sebab itu, penelitian ini diharapkan dapat membuka mata investor untuk lebih memperhatikan kesesuaian laporan keuangan terhadap Standar Akuntansi Keuangan yaitu PSAK 7, dan lebih sadar akan kehadiran pengungkapan dan transaksi pihak berelasi yang dapat berpengaruh terhadap operasional perusahaan. Bagi perusahaan, penelitian ini diharapkan dapat membantu perusahaan untuk tidak lalai dalam melakukan pengungkapan pihak berelasi terhadap Catatan atas Laporan Keuangannya (CaLK). Hal ini dapat dilihat dari 38 sampel perusahaan dimana hanya sekitar tujuh perusahaan yang telah memenuhi ketentuan pengungkapan pihak berelasi sesuai PSAK 7. Sehingga pengungkapan tersebut seharusnya tetap diungkapkan sebagaimana mestinya. Bagi penelitian selanjutnya, Penulis menyarankan agar peneliti selanjutnya dapat menggunakan independen variabel yang berbeda dan lebih bervariatif sehingga dapat menghasilkan data yang lebih baik dan mencerminkan hasil penelitian, menggunakan proksi lain seperti pada proksi transaksi pihak berelasi sehingga variabel-variabel yang mempengaruhi nilai perusahaan menjadi lebih banyak dan lebih mewakilkan, memperluas lingkup sampel atau mengganti sampel data menjadi kelompok yang lebih luas karena pada penelitian ini sampel yang dipilih merujuk kepada subsektor perusahaan yang terdaftar di BEI.

\section{DAFTAR PUSTAKA}

Ang, J. S., Cole, R. A., \& Lin, J. W. (2000). Agency costs and ownership structure. The Journal of Finance, 50(1), 81-106.

Anggraini, R. (2015). Analisis pengaruh price earning ratio (per), debt to equity ratio (der), return on asset (roa), current ratio (cr) dan firm size terhadap nilai perusahaan (pbv) pada perusahaan sektor property, real estate \& building construction yang terdaftar di Bursa Efek Indonesia (BEI) tahun 2008-2012.

Chaganti, R., \& Damanpour, F. (1991). Institutional ownership, capital structure, and firm performance. Strategic Management Journal, 12, 479-491.

Christiawan, Y. J., \& Tarigan, J. (2007). Kepemilikan manajerial: kebijakan hutang, kinerja dan nilai perusahaan. Surabaya: Universitas Kristen Petra.

Connelly, B. L., Certo, S. T., Ireland, R. D., \& Reutzel, C. R. (2011). Signaling theory: a review and assessment. Journal of Management, 37(1), 39-67. https://doi.org/10.1177/0149206310388419 (diakses pada 8 Juni 2020)

Demsetz, H., \& Villalonga, B. (2001). Ownership structure and corporate performance. Journal of Corporate Finance, 7, 209-233.

Donaldson, T., \& Preston, L. E. (1995). The stakeholder theory of the corporation: concepts, evidence, and implications. Academy of Management Review, 20(1), 65-91. 


\section{JURNALKU}

Volume 1 No. 2, Juni 2021

Eisenhardt, K. M. (1989). Agency theory: an assessment and review. Academy of Management Review, 14(1), 57-4.

Ghozali, Imam \& Ratmono, Dwi. (2017). Analisis Multivariat dan Ekonometrika: Teori, Konsep, dan Aplikasi dengan Eviews10. Semarang: Badan Penerbit Universitas Diponegoro.

Hamrouni, A., Miloudi, A., \& Benkraiem, R. (2015). Signaling firm performance through corporate voluntary disclosure. The Journal of Applied Business Research, 31(2), 609620.

Harrison, J. S., \& Wicks, A. C. (2013). Stakeholder theory, value, and firm performance. Business Ethics Quarterly, 23(1), 97-124. https://doi.org/10.1017/S1052150X00005388 (diakses pada 8 Juni 2020)

Ikatan Akuntansi Indonesia. 2014. PSAK No. 7 Yang Mengatur Tentang Pengungkapan Pihakpihak Berelasi-edisi revisi 2014. Jakarta.

Kang, M., Lee, H. Y., Lee, M. G., \& Park J. C. (2010). The association between related-party transactions and control-ownership wedge: evidence from Korea. Pacific-Basin Finance Journal. https://doi.org/10.1016/j.pacfin.2014.04.006 (diakses pada 8 Mei 2020)

Khairunnissa, Mutiara. 2018. Pengaruh Transaksi Pihak-pihak Hubungan Istimewa Terhadap

Kinerja Perusahaan. Bandar Lampung: Universitas Lampung.

Kohlbeck, M., \& Mayhew, B. W. (2010). Valuation of firms that disclose related party transactions. J. Account. Public Policy, 29, 115-137. https://doi.org/10.1016/j.jaccpubpol.2009.10.006 (diakses pada 20 April 2020)

Lubis, A. W., Bukit, R., Lubis, T. A. S. (2013). Pengaruh pengeluaran modal, penelitian dan pengembangan, transaksi pihak hubungan istimewa dan profitabilitas terhadap nilai perusahaan pada perusahaan manufaktur yang terdaftar di Bursa Efek Indonesia. Jurnal Telaah \& Riset Akuntansi, 6(1), 1-13.

Mihai, I. O., \& Radu, R. I. (2016). A literature review of accounting and auditing related parties transactions. International Conference "Risk in Contemporary Economy", 18, 406-411

Pangesti, N. G. (2020). Transaksi pihak berelasi dan nilai perusahaan: kepemilikan terdistribusi sebagai variabel moderasi. Surabaya: Universitas Airlangga.

Pasaribu, M. Y., Topowijono, \& Sulasmiyati, S. (2016). Pengaruh struktur modal, struktur kepemilikan dan profitabilitas terhadap nilai perusahaan pada perusahaan sektor industri dasar dan kimia yang terdaftar di BEI tahun 2011-2014. Jurnal Administrasi Bisnis (JAB), 35(1), 154-164.

Payne, G. T., \& Petrenko, O. V. (2019). Agency theory in business and management research. Oxford Research Encyclopedia, Business, and Management. https://doi.org/10.1093/acrefore/9780190224851.013.5 (diakses pada 8 Juni 2020)

Pozzoli, M., \& Venuti, M. (2013). Related party transactions and financial performance: is there a correlation? empirical evidence from Italian listed companies. Open Journal of Accounting, 3, 28-37. https://doi.org/10.4236/ojacct.2014.31004.

Prasetyo, Tio Andri. 2020. Analisis Pengaruh Dana Desa Dan Indeks Pembangunan Manusia Per Kabupaten/Kota Terhadap Pertumbuhan Ekonomi Regional Di Indonesia. Skripsi Diploma IV Akuntansi, Politeknik Keuangan Negara STAN. Tangerang Selatan: Tidak diterbitkan.

Pratama, A. (2018). Do related party transactions and tax avoidance affect firm value?. Review of Integrative Business and Economics Research, 7(1), 106-116.

Putri, N. A. G., Tanzil, M. N. D., \& Pratama, A. (2019). Apakah transaksi dengan pihak berelasi yang terindikasi tunneling mempengaruhi firm value?. Jurnal Edunomic, 7(1), 63-72.

Santoso, Singgih. 2018. Menguasai SPSS Versi 25. Jakarta: Elex Media Komputindo. 


\section{JURNALKU}

Volume 1 No. 2, Juni 2021

Sari, N. A., \& Artinah, B. (2018). Faktor penentu transaksi pihak berelasi: struktur kepemilikan dan tingkat pengungkapan. Banjarmasin: Universitas Lambung Mangkurat.

Septilestari, D., Maharani B., \& Agustini A. T. (2018). Analisis pengaruh pengungkapan, transaksi dan saldo pihak berelasi terhadap harga saham sektor keuangan di BEI. Jurnal Akuntansi Universitas Jember, 16(1), 13-29.

Tsai, C. C., Chang, L., \& Chang, Y. L. (2015). Related party transactions and corporate value. Journal of Economics, Business and Management, 3(10), 924-928. https://doi.org/10.7763/JOEBM.2015.V3.310 (diakses pada 8 Mei 2020)

Utomo, Agung Priyo et al. 2015. Buku Modul Perkuliahan: Analisis Regresi. Jakarta: STIS.

Widari, N. W. S., Subroto, B., \& Fuad, A. (2013). Market reaction on the information of related party transaction disclosure. Imperial Journal of Interdisciplinary Research (IJIR), 2(7), 657-663.

Young, M. N., Peng, M. W., Ahlstrom, D., \& Bruton, G. D. (2003). Principal-principal agency. Chinese Management Review, 6(1), 17-45. 